\title{
PENINGKATAN PRODUKSI PADI MELALUI DISEMINASI TEKNOLOGI DI KABUPATEN TAKALAR
}

\author{
Increasing Rice Production through Technology Dissemination \\ in Takalar District
}

\author{
Wardah Halil, Eka Triana Yuniarsih, dan Farida Arief \\ Balai Pengkajian Teknologi Pertanian Sulawesi Selatan \\ Jl. Perintis Kemerdekaan KM. 17,5 Makassar \\ e-mail: warda69.halil@gmail.com
}

Received: 13 Maret 2021; Accepted: 7 Mei 2021; Published: 25 Juni 2021

\begin{abstract}
ABSTRAK
Penyuluhan merupakan salah satu teknik penyampaian oleh penyuluh kepada pelaku utama dan pelaku usaha agar mereka tahu, mau dan mampu menolong dan mengorganisasikan dirinya agar tercapai kesejahteraan. Salah satu upaya mempercepat transfer teknologi kepada petani/pengguna adalah dengan menggunkan metode penyuluhan yang efektif. SL PTT merupakan salah satu pendekatan yang dilakukan dalam mempercepat adopsi teknologi padi, penerapan PTT pada sekolah lapang melibatkan semua pemangku kepentingan dan sumber informasi dalam memberikan informasi terkait PTT padi . Penelitian dilaksanakan di Desa Cakura kecamatan Polongbangkeng Selatan Kabupaten Takalar, analisis data menggunakan analisis deskriptif. Kesimpulan penelitian ini adalah Penggunaan teknologi PTT dapat meningkatkan produksi padi sampai dengan 85\%, Metode Penyuluhan yang disukai petani adalah Sekolah Lapang, Metode Penyuluhan dengan SDMC (Sistem Diseminasi Multi Channel) dalam Sekolah Lapang merupakan metode yang efektif dalam diseminasi teknologi padi.
\end{abstract}

Kata kunci: Produksi, diseminasi, teknologi, padi

\section{PENDAHULUAN}

Penyuluhan merupakan Pendidikan non formal kepada individua atau kelompok masyarakat yang dilakukan secara sistematik, terencana dan terarah untuk merubah perilaku untuk peningkatan produksi, pendapatan dan kesejahteraan. Menurut undang-undang no. 16 tentang SP3K tahun 2006 bahwa system Penyuluhan pertanian merupakan seluruh rangkaian pengembangan kemampuan, pengetahuan, ketrampilan dan sikap pelaku utama dan pelaku usaha melalui penyuluhan. Selain itu penyuluhan juga merupakan salah satu upaya untuk menghasilkan perubahan perilaku seperti perubahan pengetahuan, ketrampilan dan sikap.
Inovasi merupakan ide, gagasan atau praktek yang mengandung kebaruan, tidak selamanya inovasi merupakan penelitian yang mutakhir dan mendorong terjadinya suatu perubahan. Teknologi Pertanian merupakan salah satu inovasi di bidang bertanian yang dapat menghasilkan suatu perubahan, Peranan penyuluhan dalam menghasilkan suatu perubahan, seperti perubahan pengetahuan,sikap, dan ketrampilan petani sangat penting dalam upaya mempercepat adopsi inovasi dalam rangka meningkatkan produktivitas dan pendapatan petani. Keberhasilan Penyuluh mendiseminasikan teknologi ke petani dipengaruhi beberapa hal, salah satu yang penting adalah pemilihan metode Penyuluhan. 
Metode Penyuluhan merupakan cara/Teknik penyampaian oleh penyuluh kepada pelaku utama dan pelaku usaha agar mereka tahu, mau dan mampu menolong dan mengorganisasikan dirinya agar tercapai kesejahteraan. Salah satu upaya untuk mempercepat penyebaran informasi teknologi (penyuluhan) kepada para pengguna, yaitu dengan memilih metode penyuluhan yang efektif.

Pemerintah telah menyusun metodemetode dalam menyampaikan teknologi-teknologi pertanian, seperti pada Peraturan Menteri Pertanian Nomor: 52/Permentan/OT.140/12/2009 tentang Metode Penyuluhan Pertanian. Peraturan menteri (Permen) pertanian tersebut telah disusun kementerian pertanian dengan menimbang dari peraturan-peraturan yang sebelumnya pernah dibuat oleh pemerintah seperti Undang-undang Nomor 16 Tahun 2006 tentang Sistem Penyuluhan Pertanian, Perikanan dan Kehutanan. Permen tersebut berisikan metode-metode yang dapat memandu penyuluh pertanian, seperti teknik komunikasi, metode jumlah sasaran dan metode indera penerima dari sasaran (Wiriatmadja 1990). Penggunaan metode-metode tersebut dapat didasarkan berbagai pertimbangan yang terjadi dilapangan (Kemenpan 2009).

Penerapan teknologi yang cenderung melambat menjadikan berbagai permasalahan yang rumit. Hal tersebut disebabkan oleh lambannya arus/transfer inovasi yang selama ini ada. Sistem penyuluhan inovasi teknologi pertanian perlu memperoleh dukungan yang kuat agar proses penyampaian dan adopsi teknologi pertanian dapat berlangsung cepat dan terkendali. Karakteristik petani yang beragam menuntut pentingnya suatu penyelenggaraan penyuluhan/diseminasi yang lebih tepat sasaran dengan pendekatan-pendekatan baru yang lebih objektif. Berbagai upaya dilakukan pemerintah dalam upaya mentransfer inovasi teknologi kepada petani melalui berbagai saluran dan metode, salah satunya adalah melalui pendekatan PTT. Namun demikian, belum seluruh komponen teknologi di adopsi oleh petani. Salah satu faktor yang mempengaruhi adopsi teknologi adalah efektifitas metode penyuluhan yang digunakan.
Sejumlah teknologi pertanian yang dihasilkan oleh Badan Litbang Pertanian diantaranya telah digunakan secara luas dan terbukti menjadi tenaga pendorong utama pertumbuhan dan perkembangan usaha dan sistem agribisnis berbagai komoditas pertanian. Namun demikian dari evaluasi eksternal maupun internal menunjukkan bahwa kecepatan dan tingkat pemanfaatan inovasi yang dihasilkan Badan Litbang Pertanian cenderung melambat, bahkan menurun (Simatupang, 2004). Berkaitan dengan itu untuk mengetahui efektivitas metode penyuluhan dalam SLPTT padi, maka dilakukan penelitian.

\section{METODE PENELITIAN}

Penelitian dilaksanakan di kecamatan Polongbangkeng Selatan, desa Cakura Kabupaten Takalar. Untuk memperoleh gambaran dari berbagai permasalahan dan pemahaman yang berkaitan dengan pelaksanaan SL-PTT maka fokus penelitian ini ditujukan kepada petani alumni SLPTT tahun 2018. Penelitian ini menggunakan metode survey dengan melakukan wawancara. Wawancara bertujuan untuk memperoleh data primer dari responden dengan menggunakan daftar pertanyaan atau kuesioner. Data dianalisis dengan menggunakan analisis deskriptif

\section{HASIL DAN PEMBAHASAN}

\section{Wilayah}

Polongbangkeng Selatan terletak $10 \mathrm{~km}$ di sebelah selatan ibukota Kabupaten Takalar. Ibu kota Polongbangkeng selatan terletak di Kelurahan Bulukunyi yang sebelah utara berbatasan dengan polongbangkeng utara, sebelah timur berbatasan dengan Kab. Jeneponto, sebelah Selatan berbatasan dengan Mangarabombang dan sebelah barat berbatasan dengan Pattalassang . Luas wilayah Kecamatan Polongbangkeng selatan adalah 88.07 $\mathrm{km} 2$ atau 15,54\% dari total luas Kab. Takalar yang mempunyai 4 Desa dan 6 kelurahan. Luas wilayah kecamatan Polongbangkeng Selatan menurut Desa/kelurahan Tahun 2018 dapat dilihat pada tabel 1.

Diterbitkan Oleh,

Unit Penelitian dan Pengabdian Masyarakat, Politeknik Pembangunan Pertanian Gowa

http://ejournal.polbangtan-gowa.ac.id 
DOI: $10.52625 /$ j-agr-sosekpenyuluhan.v17i1.184

Tabel 1. Luas wilayah Kecamatan Polongbangkeng Selatan menurut Desa/Kelurahan tahun 2018

\begin{tabular}{lcc}
\hline \multicolumn{1}{c}{ Desa/Kelurahan } & Luas $(\mathrm{Km} 2)$ & $\%$ \\
\hline Pa'bundukang & 3,14 & 3,56 \\
Canrego & 8,38 & 9,52 \\
Bontokadatto & 7,01 & 7,96 \\
Bulukunyi & 13,04 & 14,81 \\
Cakura & 11,46 & 13,01 \\
Lantang & 17,22 & 19,55 \\
Moncongkomba & 13,23 & 15,02 \\
Patte'ne & 4,82 & 5,47 \\
Rajaya & 6,02 & 6,84 \\
Su'rulangi Jumlah & 3,75 & 4,26 \\
& 88,07 & 100 \\
\hline
\end{tabular}

\section{Iklim}

Curah hujan dipengaruhi oleh keadaan iklm dan perputaran arus udara.. Tahun 2016 rata-rata hujan dalam setahun sekitar 12 hari dengan curah hujan sekitar 18,17 mm. Jumlah hari hujan banyak terjadi pada bulan Januari dan bulan Desember, sedang curah hujan banyak terjadi pada bulan Januari dan Pebruari. Jumlah Curah Hujan dan Hari hujan menurut bulan di Kecamatan Polongbangkeng Selatan Tahun 2018 dapat dilihat pada tabel 2.

Tabel 2. Jumlah curah hujan dan hari hujan menurut bulan di Kecamatan Polongbangkeng Selatan tahun 2018

\begin{tabular}{|c|c|c|}
\hline Bulan & Curah Hujan & Hari Hujan \\
\hline Januari & 518 & 18 \\
\hline Pebruari & 473 & 17 \\
\hline Maret & 129 & 14 \\
\hline April & 176 & 16 \\
\hline Mei & 54 & 7 \\
\hline Juni & 104 & 8 \\
\hline Juli & 33 & 6 \\
\hline Agustus & 20 & 10 \\
\hline September & 234 & 13 \\
\hline Oktober & 325 & 15 \\
\hline November & 274 & 24 \\
\hline Desember & 367 & - \\
\hline
\end{tabular}

\section{Penduduk}

Penduduk adalah orang yang bertempat tinggal ataupun yang sedang berdomisili disuatu wilayah/Negara. Pertumbuhan penduduk adalah suatu perubahan populasi yang terjadi sewaktuwaktu dan bisa dihitung sebagai perubahan dalam jumlah individu atau dalam sebuah populasi menggunakan satuan "per waktu unit" untuk pengukuran. Jumlah penduduk di Kecamatan Polongbangkeng Selatan umumnya mengalami kenaikan, namun laju pertumbhan penduduk mengalami penurunan, seperti pada tabel 3 .

Pada umumnya petani di kecamatan Polongbangkeng selatan, melakukan usahatani padi. Lahan sawah yang digunakan terdiri dari lahan sawah irigasi dan lahan sawah non irigas. Lahan sawah Irigasi ditanami padi 2 kali dalam setahn, sedangkan lahan non irigasi ditanami padi 1 kali setahun. Adapun Luas lahan sawah menurut Desa/Kelurahan di Kecamatan Polongbangkeng Selatan tahun 2018 dapat dilihat pada tabel 4. Sedangkan luas tanam padi dilihat pada table 5 . 
DOI: $10.52625 /$ j-agr-sosekpenyuluhan.v17i1.184

Tabel 3. Jumlah penduduk dan laju pertumbuhan penduduk menurut Desa/Kelurahan di Kec. Polongbangkeng Selatan tahun 2016

\begin{tabular}{lcccc}
\hline \multirow{2}{*}{\multicolumn{1}{c}{ Desa/Kelurahan }} & \multicolumn{2}{c}{ Jumlah Penduduk (jiwa) } & \multicolumn{2}{c}{ Laju Pertumbuhan Penduduk (\%) } \\
\cline { 2 - 5 } & 2015 & 2016 & $2010-2016$ & $2015-2016$ \\
\hline Pa'bundukang & 2.318 & 2.338 & 0,98 & 0,86 \\
Canrego & 2.693 & 2.707 & 0,65 & 0,52 \\
Bontokadatto & 3.332 & 3.373 & 1,31 & 1,23 \\
Bulukunyi & 2.730 & 2.747 & 0,73 & 0,62 \\
Cakura & 2.829 & 2.845 & 0,66 & 0,57 \\
Lantang & 3.865 & 3.895 & 0,91 & 0,78 \\
Moncongkomba & 3.635 & 3.662 & 0,84 & 0,74 \\
Patte'ne & 3.001 & 3.018 & 0,65 & 0,57 \\
Rajaya & 2.266 & 2.294 & 1,31 & 1,24 \\
Su'rulangi & 1.401 & 1.408 & 0,65 & 0,50 \\
\multicolumn{1}{c}{ Jumlah } & 28.070 & 28.287 & 0,88 & 0,77 \\
\hline
\end{tabular}

Tabel 4. Luas lahan sawah menurut Desa/Kelurahan di Kecamatan Polongbangkeng Selatan (ha) 2018

\begin{tabular}{lccc}
\hline \multicolumn{1}{c}{ Desa/Kelurahan } & Irigasi & Non Irigasi & Jumlah \\
\hline Pa'bundukang & - & 158,66 & 158,66 \\
Canrego & - & 317,07 & 317,07 \\
Bontokadatto & 80.00 & 75,35 & 155,35 \\
Bulukunyi & 539,52 & 150,15 & 689,67 \\
Cakura & 250,42 & 147,58 & 398,00 \\
Lantang & 837 & 100 & 937 \\
Moncongkomba & 144,56 & 437,58 & 582,14 \\
Patte'ne & 195,35 & 171,70 & 367,05 \\
Rajaya & - & 126,50 & 126,50 \\
Su'rulangi & 75,00 & 124,56 & 199,56 \\
\multicolumn{1}{c}{ Jumlah } & $2.121,85$ & $1.809,15$ & $3.931,00$ \\
\hline
\end{tabular}

Tabel 5. Luas tanam padi di Kecamatan Polongbangkeng Selatan tahun 2015-2016

\begin{tabular}{lcc}
\hline Komoditas & Tahun 2015 & Tahun 2016 \\
\hline Padi sawah & 4.900 & $6.311,4$ \\
Padi ladang & 1.140 & 876,0 \\
\hline
\end{tabular}

\section{Penerapan Teknologi Petani}

Umumnya di kecamatan Polongbangkeng selatan petani melakukan budidaya padi dengan menggunakan teknologi yang dilakukan menurut kebiasaan petani diantaranya yaitu penggunaan benih tanpa label dan biasanya benihnya berasal dari penanaman sebelumnya dan sudah beberapa kali di gunakan, dan beberapa komponen budidaya lainnya menurut kebiasaan petani. PTT (Pengelolaan Tanaman terpadu) adalah suatu pendekatan inovatif dalam upaya peningkatan efisiensi usaha tani padi sawah dengan menggabungkan berbagai komponen teknologi yang saling menunjang dan dengan memperhatikan penggunaan sumber daya alam secara bijak agar memberikan pengaruh terhadap produktivitas.

Diterbitkan Oleh, 
Komponen teknologi yang diterapkan dalam PTT padi meliputi 1) varietas unggul, inhibrida(hibrida); 2) benih bermutu dan berlabel;3) pemberian bahan organik melalui pengembalian jerami ke sawah atau dalam bentuk kompos atau pupuk kandang; 4) pengaturan populasi tanaman secara optimun; 5) pemupukan berdasarkan kebutuhan tanaman dan status hara tanah; 6) pengendalian OPT (Organisme Pengganggu Tanaman) dengan pendekatan PHT
(Pengendalian Hama Terpadu). 7) pengolahan tanah sesuai musim dan pola tanam; 8) penggunaan bibit muda ( $<21$ hari); 9) tanam bibit 1-3 batang per lubang; 10) pengairan secara efektif dan efisien; 11) penyiangan dengan landak atau gasrok; 12) panen tepat waktu dan gabah segera rontok (Anonim, 2009a). Adapun teknologi budidaya padi cara petani dan teknologi PTT dapat dilihat pada tabel 6.

Tabel 6. Teknologi budidaya padi cara petani dan cara introduksi teknologi PTT Padi Desa Cakura Kec. Polongbangkeng Selatan Kabupaten Takalar

\begin{tabular}{|c|c|c|c|}
\hline No. & Teknologi & Cara Petani & Introduksi Teknlogi PTT \\
\hline \multirow[t]{4}{*}{1.} & Benih & Tidak berlabel & Label/sertifikat \\
\hline & Jumlah (kg/ha) & $30-40 \mathrm{~kg} / \mathrm{ha}$ & $25 \mathrm{~kg} / \mathrm{ha}$ \\
\hline & Varietas & Ciherang, Cigeulis, Ciliwung & Inpari $4,41,42$ \\
\hline & Perlakuan Benih & Tidak ada & Agrimeth \\
\hline \multirow[t]{2}{*}{2.} & Pemupukan (dosis kg/ha) & Tidak sesuai rekomendasi & Sesuai Rekomendasi \\
\hline & & Urea & Urea, KCl, SP36 \\
\hline 3. & Pelakuan pra olah tanah & $\begin{array}{l}\text { Sanitasi lahan dan penyomprotan } \\
\text { herbisida }\end{array}$ & $\begin{array}{l}\text { Sanitasi lahan dan } \\
\text { penyomprotan herbisida }\end{array}$ \\
\hline 4. & Pengolahan tanah & Olah tanah sempurna & Olah tanah sempurna \\
\hline 5. & Cara tanam & Tapin & Legowo 2:1 \\
\hline 6. & Jarak tanam (tapin) & $25 \times 25 \mathrm{Cm}$ & $(25 \times 12,5 \times 50) \mathrm{cm}$ \\
\hline 7. & Umur bibit & Lebih 21 hari & $15-20$ hari \\
\hline \multirow[t]{5}{*}{8.} & Pemeliharaan & $\begin{array}{l}\text {-rumput dan tanaman lain } \\
\text { dibiarkan }\end{array}$ & Ada \\
\hline & Penyulaman & Umumnya Tidak ada & Ada \\
\hline & Waktu Pemupukan & $\mathrm{I}-2 \mathrm{kali}$ & 3 kali \\
\hline & Penyiangan & Umumnya Tidak ada & Ada \\
\hline & $\begin{array}{l}\text { Pengendalian hama penyakit } \\
\text { Panen }\end{array}$ & Secara Kimia & Preventif dan secara kimia \\
\hline 9. & - Waktu panen & $\begin{array}{l}\text { Masak fisiologis }(90 \%) \\
\text { menguning, } \\
\text { Kadar air } 25 \text {-30 } \\
\text { Mesin Panen }\end{array}$ & $\begin{array}{l}\text { Masak fisiologis }(90 \%) \\
\text { menguning, } \\
\text { Kadar air } 25 \text {-30 } \\
\text { Mesin Panen }\end{array}$ \\
\hline 10. & $\begin{array}{l}\text { Pasca panen } \\
\text { - Pengeringan } \\
\text { - Sortasi }\end{array}$ & $\begin{array}{l}\text { Penjemuran dengan Sinar } \\
\text { matahari }\end{array}$ & $\begin{array}{l}\text { Penjemuran dengan Sinar } \\
\text { matahari, kemas, label }\end{array}$ \\
\hline 11. & Produksi & Rata-rata 3- 4 ton/ha & $5,46-6,7$ ton/ha \\
\hline
\end{tabular}

Diterbitkan Oleh, 
Dari tabel 6 dapat dilihat bahwa penggunaan beberapa komponen teknologi PTT padi seperti penggunaan benih berlabell dan bersertifikat, penanaman bibit muda, cara tanam legowo 2: 1, pemupukan berimbang dan sesuai rekomendasi, PHT, dan perbaikan pasca panen padi dapat meningkatkan hasil produksi padi dari ratarata 3-4 ton/ha menjadi 5,46-6,7 ton/ha.

\section{Metode Penyuluhan}

Metode dan teknik penyuluhan pertanian dapat diartikan sebagai cara atau teknik penyampaian materi penyuluhan oleh para penyuluh kepada para petani beserta keluarganya baik secara langsung maupun tidak langsung, agar mereka tahu, mau dan mampu menerapkan inovasi (teknologi baru). Wiriatmadja (1990), menyatakan bahwa metode penyuluhan pertanian, bisa dilakukan berdasarkan teknik komunikasi, jumlah sasaran dan indera penerima sasaran.

\section{Metode berdasarkan teknik komunikasi}

Berdasarkan teknik komunikasi, metode penyuluhan dibedakan antara yang langsung (muka ke muka/ face to face communication) dan yang tidak langsung (indirect communication). Metode yang langsung digunakan pada waktu penyuluh berhadapan muka dengan sasarannya sehingga memperoleh respon dari sasarannya dalam waktu yang relatif singkat. Namun metode penyuluhan tak langsung tidak memungkinkan penyuluh mendapatkan respon dari sasaran dalam waktu realtif singkat (Mardikanto 1993). Metode tidak langsung ini dapat digunakan sebagai upaya menarik perhatian dan menggugah hati sasaran.

\section{Metode berdasarkan jumlah sasaran dan proses adopsi}

Berdasarkan jumlah sasaran dan proses adopsi maka penyuluhan dibedakan menjadi:

1. Metode dengan hubungan perseorangan yaitu metode yang berhubungan langsung maupun tidak langsung dengan masing-masing orangnya (petani). Misalnya adalah kunjungan ke rumah, ke sawah, ke kantor, pengiriman surat kepada perseorangan dan hubungan telepon.

2. Metode dengan hubungan dapat d kelompok digunakan oleh penyuluhan pertanian/petemakan untuk menyampaikan pesan kepada kelompok. Contohnya adalah pertemuan, demontrasi, karya wisata, pameran, perlombaan, kursus, diskusi kelompok dan lain-lain, dan

3. Metode dengan hubungan masal digunakan oleh penyuluh untuk menyampaikan pesan langsung atau tidak langsung kepada banyak orang sekaligus pada waktu yang hampir bersamaan. Contohnya adalah pidato dalam pertemuan besar, siaran pedesaan lewat radio dan televisi, penyebaran bahan cetakan, penempelan poster, pembentangan spanduk dan lain-lain.

\section{Metode berdasarkan indera penerima}

Berdasarkan metode ini, penyuluhan dapat digolongkan menjadi metode yang dapat dilihat, metode yang dapat didengar serta metode yang dapat dilihat dan didengar. Metode yang dapat dilihat, pesan penyuluhannya diterima oleh sasaran melalui indera penglihatan (Suwandi 2006). Contohnya adalah metode publikasi barang cetakan, gambar, poster, leaflet dan lain-lain.. Dalam metode yang dapat didengar pesan penyuluhannya diterima oleh sasaran melalui indera pendengaran. Contohnya siaran lewat radio dan tape recorder, hubungan melalui telepon, pidato ceramah dan lain-lain. Sedangkan metode yang dapat dilihat dan didengar pesan penyuluhannya diterima oleh sasaran melalui indera penglihatan dan pendengaran sekaligus. Contohnya adalah metode pertunjukan film bersuara, siaran lewat televisi, wayang, kursus berupa pelajaran dikelas dan prakteknya, karya wisata, pameran dengan penjelasan lisan.

Pemilihann metode yang tepat merupakan salah satu faktor yang menentukan keberhasilan kegiatan penyuluhan. Jadi pemilihan metode harus tepat, sesuai dengan keadaan. Menurut Soegiyanto (2001) ada beberapa faktor yang dapat menjadi dasar dalam memilih metode penyuluhan, yaitu sasaran, sumber daya penyuluh, keadaan daerah dan kebijaksanaan pemerintah.

1. Sasaran; Hal yang perlu diperhatikan tingkat pengetahuan sasaran, ketrampilan dan sikap sasaran, kondisi sosial budaya sasaran penyuluhan, banyaknya sasaran yang dicapai.

2. Sumberdaya Penyuluhan; Hal yang perlu

Diterbitkan Oleh,

Unit Penelitian dan Pengabdian Masyarakat, Politeknik Pembangunan Pertanian Gowa

http://ejournal.polbangtan-gowa.ac.id 
dipertimbangan untuk sumberdaya penyuluhan pertanian ini, yaitu kemampuan penyuluh yang meliputi pengusaan ilmu dan ketrampilan serta sikap yang dimiliki. Materi penyuluhan yang akan disampaikan Ketersediaan sarana dan biaya penyuluhan.

3. Keadaan Daerah; Keadaan daerah juga mempengaruhi dalam pertimbangan dalam memilih metode penyuluhan. Keadaan daerah yang mempengaruhi adalah musim dan iklim, keadaan usahatani, keadaan lapangan.

4. Kebijaksanan Pembangunan Pertanian; Kebijakan juga mempengaruhi metode yang diambil nantinya. Kebijakan tersebut dapat berasal dari pemerintah pusat dan daerah ataupun masyarakat petani.

5. Tahapan dan Kemampuan Adopsi; Tahapan adopsi inovasi pada diri pelaku utama dan atau pelaku usaha berlangsung melalui serangkain pengalaman mental psikolog secara bertahap sebagai berikut :a. Tahap penumbuhan perhatian; b. Tahap penumbuhan minat; c. Tahap menilai, dima pelaku utama dan/atau pelaku usaha mampu membuat perbandingan; d. Tahap mencoba, dan tahap e: Tahap menetapkan.

\section{Sekolah Lapang}

Sekolah lapang adalah SL-PTT (Sekolah Lapang Pengelolaan Tanaman Terpadu) adalah tempat pendidikan non formal bagi petani dari petani, untuk meningkatkan pengetahuan dan ketrampilan dalam mengenali potensi, menyusun rencana usaha tani, mengatasi permasalahan, mengambil keputusan dan menerapkan teknologi yang sesuai dengan kondisi sumberdaya setempat secara sinergis dan berwawasan lingkungan sehingga usahataninya menjadi efisien, berproduktivitas tinggi dan berkelanjutan, dengan pendampingan dari penyuluh pertanian, petugas pertanian maupun dari peneliti.

Menurut Anonim (2008) sekolah lapang adalah bentuk sekolah yang seluruh proses belajarmengajarnya dilakukan dilapangan. Diharapkan melalui SL-PTT terjadi percepatan penyebaran teknologi PTT dari peneliti ke petani peserta dan selanjutnya langsung difusi secara alamiah dari alumni SL-PTT kepada petani sekitarnya . Tujuan utama SL-PTT adalah mempercepat teknologi PTT dari peneliti atau narasumber lainnya ke petani peserta dan kemudian berlangsung difusi secara alamiah dari alumni SL-PTT kepada petani sekitarnya. Dengan demikian SL-PTT adalah bentuk sekolah lapang yang sebagian besar kegiatannya dilapangan, dengan mengaktifkan petani dengan tujuan untuk mempercepat difusi teknologi PTT ke petani lainnya.

Setiap lokasi SL-PTT dipandu oleh pemandu lapang yang terdiri dari penyuluh pertanian, Pengamat Organisme Pengganggu Tanaman (POPT), Pengawas Benih Tanaman (PBT) dan peneliti. Peserta adalah petani dalam kawasan 15-25 ha yang dibagi dalam beberapa subkelompok tani yang jumlahnya sekitar 20-30 orang per subkelompok. Dari 25 ha lahan SL-PTT, 24 ha diantaranya dikelola oleh subkelompok tani dan sisanya 1 ha untuk laboratorium lapang dikelola oleh pemandu lapang atau petugas PL II dari Dinas Pertanian atau Balai Pengkajian Teknologi Pertanian setempat. Dengan demikian, hal ini memberi peluang bagi petani mengetahui teknologi PTT melalui kegiatan dalam laboratorium lapangan, Adapun Pola SL-PTT dapat dilihat pada Gambar 1.

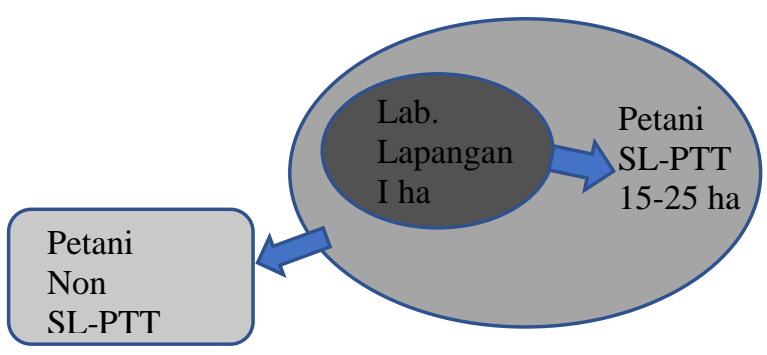

Gambar 1. Pola SL-PTT

\section{Metode penyuluhan dalam SL-PTT}

Berdasarkan Teknik komunikasi, metode penyuluhan yang digunakan dalam SL-PTT merupakan gabungan metode tatap muka langsung dan metode tatap muka tidak langsung, dimana penyuluh berhadapan muka langsung dengan sasarannya sehingga dalam waktu yang singkat dapat memperoleh respon dari sasarannya, sedangkan metode tidak langsung, penyuluh menyampaikan pesannya melalui perantara/medium. Berdasarkan sasaran dan proses 
adopsi, metode perseorangan dan berhubungan langsung dengan petani, misalnya kunjungan ke sawah, konsultasi melalui telpon dan lain sebagainya, sedangkan metode hubungan dengan kelompok sepeti pertemuan, demonstrasi, pameran, diskusi, dan sebagainya. Metode dengan hubungan massal adalah penyuluh menyampaikan pesan langsung atau tidak langsung kepada banyak orang sekaligus pada waktu yang hampir bersamaan seperti temu lapang, penyebaran bahan cetakan, penempelan poster siaran lewat radio dan sebagainya. Gabungan beberapa metode ini terdapat dalam Sekolah Lapang. Karna ada tatap muka langsung, ada teknologi yang disampaikan, pameran, diskusi umpan balil, temu lapang, leaflet, brosur dan sebagainya. Berdasarkan hal tersebut, beberapa metode penyuluhan yang disukai petani padi dalam dilihat pada tabel 7 .

Tabel 7. Metode penyuluhan yang disukai petani peserta sekolah lapang

\begin{tabular}{|c|c|c|c|}
\hline No & Uraian & Jumlah responden & Persentase $(\%)$ \\
\hline 1 & Demplot & 21 & 84 \\
\hline 2 & Pelatihan & 15 & 60 \\
\hline 3 & Temu lapang & 19 & 76 \\
\hline 4 & Temu Karya & 5 & 20 \\
\hline 5 & Temu Usaha & 18 & 72 \\
\hline 6 & Workshop & 6 & 24 \\
\hline 7 & Sekolah lapang & 25 & 100 \\
\hline 8 & Kursus tani & 10 & 40 \\
\hline 9 & Study banding/Karya wisata & 11 & 44 \\
\hline 10 & Lainnya & 7 & 28 \\
\hline
\end{tabular}

Dari tabel 7 dapat dilihat bahwa umumnya petani menyukai sekolah lapang, demplot, temu lapang dan temu usaha, hal tersebut disebabkan karena dalam sekolah lapang,ada demplot yang dilakukan oleh petani dalam laboratorium lapangan (LL), mulai pengolahan lahan, penanaman, pemupukan, pengendalian hama penyakit, panen dan pasca panen semua dilakukan oleh petani sendiri dan didampingi oleh berbagai sumber informasi, seperti dari Balai penelitian Padi, BPTP,BPSB,POPT, Dinas Pertanian, Peneliti dan Penyuluh.Pertemuan ini dilakukan setiap tahap kegiatan, dan dihadiri oleh anggota kelompok, Selanjutnya diakhir kegiatan disekolah lapang dilakukan temu lapang dengan mengundang beberapa petani sekitarnya untuk melihat teknologi yang diintroduksikan, terdapat ajang komunikasi secara langsung dengan peneliti, penyuluh, penentu kebijakan, swasta dan elemen terkait lainnya dan bisa berdiskusi dan mendapatkan respon balik secara langsung. Adapun komunikasi dengan sumber informasi yang diperoleh petani selama SL-PTT dapat dilihat pada table 8.
Dari tabel 8, dapat dilihat bahwa dalam pelaksanaan sekolah lapang, beberapa keterlibatan sumber informasi dan saling terkait yang turut mengambil bagian sesuai dengan peranannya masing-masing. Mulai dari pengenalan varietas, pengolahan tanah sampai dengan pemasaran, petani didampingi oleh berbagai sumber informasi, mulai dari balai penelitian Padi, BPSB, POPT, Peneliti, Penyuluh, Kios tani, gapoktan dan swasta, partisipasi setiap pelaku utama dan pelaku usaha saling terkait dalam rangka keberhasilan SL-PTT ini. Berkenaan dengan hal tersebut, di Badan Litbang Pertanian dikenal dengan model penyuluhan dengan pen-dekatan model Spektrum Diseminasi Multi Channel (SDMC). Dengan pendekatan SDM-C, kegiatan penyuluhan dikembangkan dengan memanfaatkan berbagai saluran kom-unikasi dan pemangku kepentingan (stakeholders) yang terkait. Penyebaran teknologi tidak lagi dilakukan hanya pada satu pola penyuluhan, tetapi dilakukan secara multi channel sehingga diharapkan seluruh inovasi pertanian hasil penelitian di lingkup Badan Litbang Pertanian

Diterbitkan Oleh, 
dapat didistribusikan secara cepat kepada pengguna (Gapok-tan/Poktan/petani, Pemda, BUMN, Pengambil keputusan nasional/ daerah, penyuluh,
Pengusaha/swasta/ industri, Peneliti/ Ilmuwan) melalui berbagai media secara simultan dan terkoordinasi.

Tabel 8. Sumber Informasi Berdasarkan Materi yang dibutuhkan petani SL-PTT padi

\begin{tabular}{cll}
\hline No & \multicolumn{1}{c}{ Materi } & \multicolumn{1}{c}{ Sumber Informasi } \\
\hline 1 & Pengenalan Varietas Padi & BB Padi, BPTP, BPSB, Penyuluh \\
2 & Perlakuan Benih Padi & BPTP, Penyuluh, BPSB \\
3 & Pengolahan Tanah & Penyuluh \\
4 & Pemupukan & Penyuluh, kios tani \\
5 & Pengendalian Hama Penyakit tanaman & POPT, kios tani, penyuluh \\
6 & Praktek Pembuatan Pupuk Organik & BPTP \\
7 & Pembuatan Pestisida nabati (Moll) & POPT \\
9 & Penggunaan BWD & BPTP,Dinas Pertanian \\
11 & Panen dan Pasca panen Padi & Penyuluh, peneliti \\
12 & Pemasaran & Swasta, Kiostani, Gapoktan \\
\hline
\end{tabular}

\section{Peran Badan Litbang Pertanian dalam Diseminasi Inovasi Pertanian}

Badan Litbang Pertanian sebagiai penyedia teknologi dari kegiatan penelitian dan pengkajian (litkaji) telah banyak menghasilkan inovasi berupa teknologi, data dan informasi, konsep, model, metodologi, cara dan lain-lain. Inovasi tersebut perlu didesiminasikan agar sampai ke pelaku utama dan pelaku usaha. Karena itu, kebijakan yang diambil dalam diseminasi inovasi pertanian oleh Badan Litbang Pertanian adalah mempergunakan suatu pendekatan strategi atau model yang mampu menjangkau pemangku kepentingan yang luas dengan memanfaatkan berbagai media dan saluran komunikasi yang sesuai dengan karakteristik masing-masing pemangku kepentingan. Strategi atau model tersebut dikenal dengan nama Spektrum Diseminasi Multi Channel (SDMC).

Pendekatan model Spectrum Diseminasi Multi Channel (SDMC), yaitu suatu terobosan mempercepat dan memperluas jangkauan diseminasi inovasi teknologi budi daya dengan memanfaatkan berbagai saluran komunikasi dan pemangku kepentingan (stakeholder) yang terkait secara optimal melalui berbagai media secara simultan dan terkoordinasi (Balitbangtan 2011). Diseminasi inovasi teknologi dengan pola/model SDMC yang diawali dengan sosialisasi dan advokasi kepada para pemangku kepentingan sehingga yang bersangkutan dapat menjadi penyalur inovasi teknologi kepada petani, Sekolah lapang (SL), penerbitan dan penyebarluasan media cetak leaflet serta pelaksanaan demplot teknologi budi daya dan pascapanen (dimana ditentukan satu orang petani kooperator untuk masing-masing lokasi)

Ada tiga komponen penting yang saling terkait antara satu sama dalam pendekatan SDMC, yakni generating system, delivery system dan receiving system.

1. Pada tingkat generating system, sumber inovasi teknologi yang dikembangkan bersumber dari Balitbangtan yang terdiri dari Pusat Penelitian, Balai Besar, Balit, BPTP, dan Lolit. Dalam pendekatan ini BPTP berperan ganda, sebagai penyedia teknologi sekaligus sebagai penyalur teknologi untuk mendiseminasikan teknologi yang bersumber dari Puslit/Balit dan Balai Besar. Hal ini sesuai dengan yang dilakukan dalam SL-PTT dimana kegiatan teknologi yang di desiminasikan merupakan hasil penelitian dari beberapa Balai penelitian di Indonesia, hasil penelitian tersebut telah teruji dan didesiminasikan. Jalur komunikasi yang dilakukan untuk menyebarluaskan teknologi dilakukan melalui cara langsung ke pengguna (pelaku usaha dan pelaku utama), atau dilakukan melalui institusi yang berperan sebagai delivery system.

Diterbitkan Oleh,

Unit Penelitian dan Pengabdian Masyarakat, Politeknik Pembangunan Pertanian Gowa

http://ejournal.polbangtan-gowa.ac.id 
2. Pada delivery system, penyampaian informasi teknologi dari sumber teknologi kepada pengguna dilakukan dengan mengoptimalkan pemangku kepentingan dan memanfaatkan media diseminasi. Pemangku kepentingan yang terkait dengan diseminasi ini diantaranya Pustaka, lembaga penyuluhan, LSM, Ditjen teknis, BPTP, Adapun jenis mediasi dan saluran komunikasi dibedakan atas empat bentuk, yaitu: 1) pameran (in-house visitor display, public-display/expo, visitor plot/petak percontohan, technology showcase/ gelar teknologi); 2) forum pertemuan (temu informasi, temu lapang, temu aplikasi teknologi, rapat kerja, rapat teknis, seminar, simposium, pelatihan, lokakarya, sekolah lapang, kegiatan partisipatif lainnya), 3) media cetak (buku, booklet, komik, brosur, leaflet, flyer, poster, baliho, koran, majalah/jurnal, tabloid, warta/newsletter, buletin, liputan), 4) media elektronik/digital (radio, televisi, internet, mobile phone (WAP), SMS Center, CD/VCD/DVD), dan 5) media sosial (twitter, youtube, facebook).

3. Pada receiving system, target diseminasi adalah pengguna teknologi yang meliputi pelaku utama dan pelaku usaha dalam bidang pertanian. Pengguna teknologi dimaksud terdiri dari petani, baik secara individual maupun tergabung dalam kelompok tani dan Gapoktan, Pemda, BUMN, pengambil keputusan nasional/daerah, penyuluh, pengusaha/swasta/ industri, peneliti/ilmuwan.

\section{KESIMPULAN}

1. Penggunaan teknologi PTT padi dapat meningkatkan produksi sampai dengan $85 \%$.

2. Metode Penyuluhan yang disukai petani adalah Sekolah Lapang.
3. Metode Penyuluhan dengan SDMC (Sistem Diseminasi Multi Channel) dalam Sekolah Lapang merupakan metode yang efektif dalam diseminasi teknologi padi.

\section{DAFTAR PUSTAKA}

Anonimous, 2008. Modul Diklat Pembekalan THL-TBPP. STPP Malang

Badan Litbang Pertanian, 2011. Panduan Umum Spektrum Diseminasi Multi Channel (SDMC). Badan Penelitian dan Pengembangan Pertanian.

Kecamatan Polongbangkeng selatan dalam Angka, 2018

Laporan akhir kegiatan Sekolah lapang Kedaulatan Pangan mendukung swasembada pangan terintegrasi dengan desa mandiri benih padi di Sulawesi Selatn 2018. Balai Pengkajian Teknologi Pertanian Sulawesi selatan 2018

Mardikanto, T. 2006. Peyuluhan Pembangunan Pertanian. Surakarta: Sebelas Maret University Press.

Petunjuk pelaksanaan Sekolah Lapang (SL) Pengelolaan Tanaman Terpadu padi

Repository, Universitas Riau, http://repository .umri,ac,id/ diakses tanggal 20 Maret 2021

Rogers E.M. 1983. Diffusion of Innovations. Third Edition. The Free Press, New York.

Soegiyanto. 2001. Dasar-dasar Penyuluhan Pertanian. Malang: Fakultas Pertanian Universitas Brawijaya.

Warda Halil, 2011. Pengaruh Belajar Sosial terhadap Adopsi teknologi Padi di Kabupaten Maros.Thesis. Universitas Gadjah Mada.

Wiriatmadja, S. 1990. Pokok Pokok Penyuluhan Pertanian. Jakarta: Yasaguna. Universitas. 